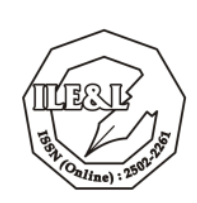

Journal Indonesian Language Education and Literature Vol. 2, No. 2, 2017

http://www.syekhnurjati.ac.id/jurnal/index.php/jeill/

\title{
STRATEGI DAN MODIFIKASI \\ KESANTUNAN TINDAK TUTUR MEMOHON OLEH MAHASISWA JEPANG PADA PROGRAM BAHASA INDONESIA BAGI PENUTUR ASING (BIPA)
}

\author{
Diana Kartika \\ Universitas Bung Hatta, Padang \\ diana.kartika67@gmail.com
}

\begin{abstract}
Abstrak
Penelitian ini berfokus pada pentingnya kesantunan berbahasa yang harus diperhatikan dalam proses komunikasi. Dalam kesantunan tindak tutur memohon diperlukan strategi dan penggunaan modifikasi yang digunakan oleh mahasiswa BIPA. Penelitian ini merupakan penelitian naturalistik. Berdasarkan analisis dapat disimpulkan bahwa strategi yang digunakan meliputi, yaitu strategi imperatif (kategori permohonan langsung), strategi menanyakan kemampuan atau kemauan (kategori tindak tutur tidak langsung secara konvensional berorientasi petutur), dan strategi isyarat (kategori permohonan paling tidak langsung). Adapun modifikasi internal berupa peranti sintaktik digunakan untuk memperhalus tindak tutur memohon, yaitu menggunakan pertanyaan dan penyisipan. Modifikasi eksternal berupa penggunaan alasan pendukung di awal dan akhir tuturan. Peranti modifikasi internal berupa syntactic down-graders dan phrasa or lexical graders dalam bentuk pertanyaan dan klausa kondisional. Adapun peranti phrasal atau lexical down-graders berupa pemarkah kesantunan dan penanda antarpribadi. Data penelitian tidak menunjukkan adanya penggunaan modifikasi eksternal oleh mahasiswa BIPA.
\end{abstract}

Kata Kunci: memohon, modifikasi, kesantunan, strategi, tindak tutur

\begin{abstract}
This study focuses on the importance of language politeness to be considered in the communication process. In the politeness of speech acts requested the necessary strategies and use of modifications used by BIPA students. This research is a naturalistic research. Based on the analysis, it can be concluded that the strategies used include imperative strategy (direct application category), strategy of ability or willingness (indirect speech acts, and the signaling strategy (the most indirect category of petition). The internal modification in the form of syntactic devices used to refine the act of invoking speech, which is using questions and insertion. External modifications include the use of supporting reasons at the beginning and end of the speech. Internal modification devices are syntactic down-graders and phrases or lexical graders in the form of questions and conditional clauses. The phrasal or lexical down-graders device is a marker of politeness and an interpersonal marker. The research data did not show any use of external modification by BIPA students.
\end{abstract}

Keywords: modifications, invoke, politeness, strategy 


\section{Journal Indonesian Language Education and Literature Vol. 2, No. 2, 2017 http://www.syekhnurjati.ac.id/jurnal/index.php/jeill/}

\section{A. Pendahuluan}

Kesantunan berbahasa sangat berperan dan harus diperhatikan dalam proses komunikasi karena penutur dan petutur akan merasa saling menghargai dalam proses komunikasi. Prinsip sopan santun merupakan prinsip percakapan yang memiliki kedudukan yang sama dengan prinsip percakapan yang lain (Rahardi, 2005: 60-66). Oleh sebab itu, pengetahuan tentang kaidah sosial pemakaian bahasa, yang berkaitan dengan kesantunan berbahasa, penting sekali dipahami pemakai bahasa, terutama oleh pembelajar bahasa asing. Oleh sebab itu, dalam mengajarkan bahasa Indonesia kepada penutur asing, pengajar perlu membekali pembelajar dengan kesantunan berbahasa dalam bertutur di samping bekal pengetahuan tata bahasa. Pembelajaran seperti itu berarti memperhatikan kompetensi komunikatif. Dengan demikian, sangat jelaslah bahwa "tindak tutur adalah alat berkomunikasi yang merupakan bagian erat dari pragmatik, karena ragmatik membahas makna tutur yang terikat dengan konteks (Hildana, 2014: 146).

Terdapat perbedaan strategi membaca antara pembaca bahasa pertama dan pembaca bahasa kedua. Penelitian ini menganalisis strategi membaca pada pembaca bahasa kedua dengan menekankan pada aktivitas membaca secara interaktif. Hal ini karena pembaca berinteraksi dengan kata-kata untuk menciptakan arti" (Wawan, 2007: 125). Penggunaan strategi tindak tutur yang dilakukan para pembelajar bahasa Indonesia sebagai bahasa asing berkaitan erat dengan kesantunan dalam bertutur. Austin (dalam Rusminto, 2010: 22) mengemukakan istilah tindak tutur sebagai "aktivitas bertutur tidak hanya terbatas pada penuturan sesuatu, tetapi juga melakukan sesuatu atas dasar tuturan itu"

Selanjutnya dijelaskan bahwa "sebuah tuturan tidak senantiasa merupakan representasi langsung dari elemen makna unsur-unsurnya karena timbulnya bermacammacam maksud yang dikomunikasikan oleh penutur dalam bertindak tutur" (Nasution, 2007: 17). Tindak tutur memohon mer bagian dari tindak tutur direktif dipilih sebagai satuan analisis penelitian ini karena beberapa faktor. Pertama, pemakaian dan realisasi yang patut dari fungsi tindak tutur direktif menjadi masalah bagi pemelajar dalam interaksi di ruang kelas karena kesempatan menggunakan tindak tutur direktif dalam interaksi sangat sedikit. Pengajarlah yang dominan menggunakan tindak tutur itu dalam ruang kelas. Dengan begitu, praktik pemakaian tindak tutur direktif di ruang kelas tidak 
seimbang dengan kenyataan hidup sehari-hari yang sangat banyak menggunakan tindak tutur direktif. Kedua, tindak ini selain melibatkan realisasi tindak tutur berupa strategi dengan menggunakan modifikasi internal, juga melibatkan strategi dengan menggunakan modifikasi eksternal. sosial, dan pengetahuan pragmalinguistik.

Strategi tindak tutur memohon oleh mahasiswa Jepang pada Program BIPA dari data tindak tutur memohon yang terkumpul di kelas BIPA adalah dua puluh dua tindak tutur memohon dalam peristiwa tutur. Pada awal-awal pertemuan sampai minggu ketiga, hampir secara keseluruhan mahasiswa masih bersifat pasif. Mahasiswa yang aktif adalah mahasiswa yang berasal dari Amerika Serikat dan Korea Selatan. Baru ketika memasuki minggu keempat, mahasiswa dari Jepang sudah mulai aktif dalam berbicara, misalnya mulai berani mengajukan pertanyaan secara langsung. Sebelumnya, jika ada hal yang tidak dipahami, mahasiswa dari Jepang banyak yang mendatangi dosen atau menunggu dosen mendekati diri mahasiswa.

Strategi tindak tutur memohon yang digunakan mahasiswa dari Jepang dalam analisis ini diklasifikasi menjadi dua berdasarkan hubungan penutur (mahasiswa) dan petutur, yaitu hubungan dengan petutur yang memiliki power seimbang dengan penutur (petutur sesama mahasiswa pada Program BIPA) dan hubungan dengan petutur yang memiliki power lebih dibanding penutur (petuturnya adalah dosen). Hanya ada empat data yang ditemukan pada situasi yang petuturnya sesama mahasiswa. Sedikitnya data itu disebabkan oleh masih sedikitnya kesempatan mahasiswa untuk berinteraksi dengan sesama mahasiswa. Selain itu, meskipun ada kesempatan untuk berinteraksi, mahasiswa masih berkecenderungan diam. Strategi yang mereka gunakan ketika melakukan tindak tutur memohon kepada sesama mahasiswa ialah strategi imperatif, yang merupakan bagian dari permohonan langsung dan strafogi menanyakan kemampuan sebagai bagian dari permohonan tidak langsung secara konvensional yang berorientasi kepada petutur.

\section{B. Metode Penelitian}

Metode penelitian yang digunakan yaitu penelitian kualitatif, Menurut Sugiyono (2011:9) metode penelitian kualitatif adalah "metode yang berdasarkan pada filsafat postpositivisme, sedangkan untuk meneliti pada objek alamiah, dimana peneliti adalah sebagai instrumen kunci, teknik pengumpulan data dilakukan dengan cara triangulasi (gabungan). Analisis data bersifat induktif atau kualitatif, dan hasil penelitian lebih 
menekankan makna daripada generalisasi”. Sedangkan Nasution (2003:18) lebih menjelaskan bahwa: "Penelitian kualitatif disebut juga penelitian naturalistik. Disebut kualitatif karena sifat data yang dikumpulkan bercorak kualitatif, bukan kuantitatif, karena tidak menggunakan alat-alat pengukur. Disebut naturalistik karena situasi lapangan penelitian bersifat "natural" atau wajar, sebagaimana adanya, tanpa dimanipulasi, diatur dengan eksperimen atau test”.

Penelitian ini dilakukan di Program Bahasa Indonesia untuk Penutur Asing (BIPA), Fakultas Ilmu Pengetahuan Budaya (FIB) Universitas Indonesia. Pengamatan partisipatoris dilakukan selama satu semester. Subjek penelitian ini adalah Mahasiswa Jepang yang mempelajari Bahasa Indonesia pada Program BIPA, Fakultas Ilmu Pengetahuan Budaya (FIB) Universitas Indonesia. Sumber data penelitian ialah mahasiswa Jepang yang belajar bahasa Indonesia pada Program BIPA. Teknik pengumpulan data penelitian yaitu, pengamatan, kuesioner yang biasa disebut tes melengkapi wacana, dan aktivitas bermain peran. Data penelitian dianalisis dan diinterprestasikan dengan mereduksi data, penyajian data, dan penarikan kesimpulan. Penyajian data dilakukan berdasarkan analisis strategi dan modifikasi mahasiswa BIPA.

\section{Hasil dan Pembahasan}

\section{Strategi dalam Kesantunan Bahasa Jepang}

Perlu dijelaskan bahwa kesulitan dalam hal pemilihan strategi oleh mahasiswa dari Jepang ketika menggunakan bahasa Indonesia sangat mungkin terjadi karena adanya perbedaan sistem kesantunan dalam bahasa Indonesia dan dalam bahasa Jepang. Kesantunan dalam bahasa Indonesia sangat dipengaruhi oleh strategi ketika bertindak tutur karena bahasa Indonesia bukanlah bahasa yang memiliki tingkat tutur secara ketat dengan' menerapkan subsistem honorifiks pada tataran feksikal, morfologis, dan sintaktis seperti dalam bahasa Jepang. Sementara itu, menurut Sachiko Ide, yang melakukan penelitian konsep kesantunan dalam bahasa Jepang, kesantunan bagi orang Jepang pada dasarnya merupakan upaya mempertahankan komunikasi yang lancar. Wakimae bukanlah kemauan karena hal tersebut tidak bergantung pada kebebasaii penutur, tetapi merupakan pilihan (bentuk gramatikal) verbal yang wajib secara sosial. Bertindak menurut wakimae berarti menunjukkan makna tempat atau peran seseorang secara verbal (dan nonverbal) dalam situasi tertentu menurut konvensi sosial. Perbedaan 
antara discerment atau wakimae dengan volition (kemauan) dapat dijelaskan sebagai berikut. Discerment direalisasikan terutama melalui berbagai bentuk kebahasaan formal, yang merupakan pilihan wajib, yang mengimplisitkan pesan tentang pemahaman penutur atas situasi sosial. Hal itu melibatkan berbagai bentuk formal seperti honorifik, pronomina, bentuk sapaan, tingkat tutur, forrnula tuturan, dan sebagainya. Sementara itu, volition dilakukan dengan cara pemilihan strategi verbal, seperti mencari persetujuan, humor, menunjukkan rasa pesimistis, meminimalisasi tekanan, dan sebagainya.

Penutur harus selalu memilih antara bentuk honorifiks atau nonhonorifiks dan hal itu selalu menyampaikan informasi tentang hubungan penutur-petutur. Bahkan, dalam menyatakan fakta pun hal itu tetap harus diperhitungkan. Pemakaian bentuk honorifiks menjadi hal yang absolut karena pemakaian honorifiks atau tidak bukanlah kebebasan pribadi yang sesuai dengan keinginan penutur. Pemakaian honorifiks secara langsung menunjukkan karakteristik sosiostruktural penutur-petutur. Keabsolutan pemakaian honorifiks ini kemudian bergandengan dengan pandangan tentang kesantunan, yang ditentukan oleh konvensi sosial yang disebut wakimae. Bertindak menurut wakimae berarti bertindak dengan menunjukkan arti seseorang secara verbal tentang tempat atau peran dalam situasi tertentu menurut konvensi sosial dan bukan kehendak pribadi.

Empat kaidah sosial Jepang yang dapat diidentifikasi sebagai dasar kesantunan dikemukakan, meliputi: 1) santunlah kepada orang yang berposisi sosial lebih tinggi, 2) santunlah kepada orang yang memiliki kekuasaan (power), 3) santunlah kepada orang yang lebih tua, dan 4) santuniah dalam latar formal yang ditentukan oleh faktor partisipan, kesempatan, dan topik pembicaraan. Jadi, dalam bahasa Jepang dan bahasabahasa lain yang secara kuat mengembangan sistem honorifiks dalam sistem tata bahasanya, pada umumnya kaidah kesantunan berkaitan dengan kaidah gramatikal. Kesantunan merupakan bagian integral dari bahasa itu sendiri dan bergantung pada karakteristik sosiostruktural penutur-petutur dan juga pada karakteristik situasi, yang harus direfleksikan dalam pilihan bahasa penutur.

Dengan kata lain, kesantunan dalam bahasa Jepang tidak dapat dijelaskan secara sederhana berkaitan dengan cara penutur memperlakukan petutur secara strategis. Kesantunan merupakan bagian yang tidak dapat dipisaih dari sistem bahasa Jepang melalui pemahaman faktor sosiokultural, yang ditransmisikan dari generasi ke generasi. 
Aspek wakimae dalam kesantunan bahasa Jepang merupakan masalah konstan dalam pemakaian bahasa karena penutur bahasa Jepang harus konstan dalam melakukan pemilihan kelas kata seperti kopula, verba, nomina, adjektiva, dan adverbia. Karena tidak ada bentuk netral, penutur bahasa-bahasa berhonorifik, termasouk bahasa Jepang, memiliki sensitivitas pada tataran formalitas dalam tindak verbalisasi seperti halnya penutur asli bahasa Inggris harus sensitif terhadap ciri nomina terbilang dan tidak terbilang untuk membedakan nomina tunggal dan jamak.

Orang Jepang pada umumnya harus memahami posisi dirinya di antara anggota lain dalam kelompok atau masyarakat dan harus mengakui kebergantungannya pada orang lain. Pengakuan dan pemertahanan posisi diri di antara orang lain lebih menguasai perilaku diri dalam semua interaksi sosial dibanding penjagaan wilayah pribadi. Hal itu termanifestasi dalam penggunaan bahasa sehingga bahasa Jepang dicirikan oleh ungkapan penghormatan, misalnya, melalui bentuk honorifik. Selanjutnya, Matsumoto menjelaskan bahwa penghormatan dalam bahasa dan kebudayaan Jepang tidak berfungsi meminimalisasi tingkat tekanan, tetapi merepresentasikan hubungan positif antara interlocutor.

Dengan demikian, dapat dinyatakan bahwa kesantunan dalam penggunaan bahasa Jepang itu adalah pilihan bahasa "otomatis" dan "wajib". Aspek sosiopragmatik seperti halnya aspek tata bahasa, merupakan pilihan unsur yang harus dilakukan ketika membuat tuturan. Hal itu dalpat ditafsirkan bahwa dalam bahasa Jepang, konsep kesantunan ditempatkan sebagai bentuk pengacuan sosial. Wakimae merupakan keharmonisan sosiopragmatik, yaitu perilaku kesantunan kebahasaan seseorang didikte oleh posisi sosialnya dan hubungan sosialnya dengan petutur. Perilaku verbal itu secara efektif berfungsi sebagai mekanisme pengacuan sosial. Bahkan, dalam tuturan yang tidak mengancam muka pun, penutur "dipaksa" untuk membuat pilihan di antara berbajai varian yang tersedia, dengan atau tanpa honorifiks menurut formalitas latar dan hubungan antarpartisipan.

\section{a) Penggunaan Modifikasi Internal}

Penutur jati bahasa Indonesia pada umumnya menggunakan modifikasi internal dalam tindak tutur memohon yang dilakukan. Modifikasi internal yang paiing umum digunakan oleh penutur jati bahasa Indonesia ialah negator, yang terdiri atas kata tidak, nggak, dan ndak. Dua negator terakhir digunakan dalam situasi informal. Selanjutnya, 
penutur jati bahasa Indonesia menggunakan modifikasi lain, yakni bentuk sapaan, pernyataan untuk meminimalisasi tekanan (imposition) seperti kata sebentar saja dan sedikit saja, kata seru penarik perhatian (appealer), yaitu kata ya. Penutur jati bahasa Indonesia seringkali mengeksploitasi peranti modifikasi internal itu dengan menggabungkan jenis peranti modifikasi yang berbeda dalam satu tuturan.

Data penggunaan modifikasi internal dalam tindak tutur memohon oleh mahasiswa Jepang menunjukkan bahwa dari sekian banyak peranti yang bisa digunakan untuk memperlunak ujaran, hanya modifikasi internal berupa pemerlunak sintaktik dengan pertanyaan dan penyisipan yang digunakan. Cara lain seperti penegasian, tag question, klausa kondisional, tidak digunakan. Modifikasi internal berupa pemerlunak leksikal/frasal yang paling sering digunakan ialah pemarkah kesantunan tolong. Sementara itu, peranti pagar pelindung (shield) seperti kata mungkin dan barangkali, peranti pagar pemerkira (approximator) seperti kata kira-kira; ungkapan pengecilan (understatement) seperti sebentar saja dan sedikit saja; peranti pagar ungkapan keraguan seperti saya kira, menurut kami, sepertinya, saya rasa, dan saya pikir tidak pernah dipakai. Dengan begitu, dapat dinyatakan bahwa mahasiswa Jepang pada Program BIPA menggunakan modifikasi internal yang berbeda dengan penutur jati bahasa Indonesia. Mahasiswa Jepang menggunakan sedikit sekali modifikasi internal dan tidak menggunakan jenis modifikasi internal yang paling umum digunakan penutur jati bahasa Indonesia.

Kurangnya penggunaan modifikasi internal oleh mahasiswa Jepang ini sesuai dengan beberapa penelitian sebelumnya, baik pemelajar tingkat dasar, menengah, maupun lanjut. Pemelajar menggunakan modifikasi internal dalam tindak tutur memohon jauh lebih sedikit dibanding penutur jati. Hal itu memunculkan dua pertanyaan. Pertama, apakah sedikitnya penggunaan modifikasi internal dalam tindak tutur memohon oleh mahasiswa Jepang itu mengurangi tingkat kesantunan atau bahkan dianggap tidak santun? Secara keseluruhan dapat dikatakan bahwa tuturan mereka tentu saja menjadi sangat kelihatan bahwa itu adalah tuturan nonpenutur jati bahasa Indonesia meskipun penutur jati bahasa Indonesia juga tidak akan dapat menunjukkan situasi mana yang mengharuskan atau mewajibkan penggunaan modifikasi internal dan situasi mana pula yang tidak mewajibkan penggunaan modifikasi internal. Meskipun begitu, terbatasnya penguasaan modifikasi internal mahasiswa Program BIPA sangat 
membatasi pilihan strategi dalam membuat tindak tutur memohon. Artinya, repertoar modifikasi internal yang dimiliki mahasiswa menjadi sangat sedikit.

Kedua, mengapa mahasiswa Jepang menggunakan modifikasi internal jauh lebih sedikit dibanding penutur jati bahasa Indonesia pada umumnya? Mahasiswa Jepang merasa kesulitan dalam memodifikasi tindak tutur memohon karena tidak adanya sistem tata bahasa Indonesia yang secara tetap digunakan untuk menunjukkan kesantunan seperti yang ada dalam sistem bahasa Jepang, yang secara tegas membagi tingkat (undak usuk) bahasa mereka ke dalam dua tingkat, yaitu tuturan santun (polite speech) dan tuturan akrab (familiar speech). Tuturan santun digunakan dalam situasi sosial seperti percakapan antara kenalan dan orang asing, sedangkan tuturan akrab digunakan dalam percakapan akrab antara teman baik atau anggota keluarga. Perbedaan dua tingkatan bahasa itu tampak pada akhir kalimat dan pilihan kosakata.

Selain itu, sulitnya mahasiswa dalam menambah modifikasi internal dalam tindak tutur memohon disebabkan sering terpajankannya penggunaan kata tolong dalam kehidupan mereka sehari-hari. Berdasarkan hasil wawancara, mahasiwa berpikir bahwa dengan menggunakan kata tolong, tindak tutur memohon mereka dipastikan santun kepada siapa. pun. Paclahal, dalam kehidupan sehari-hari penutur jati bahasa Indonesia tidak begitu. Penggunaan kata tolong masih akan disertai modifikasi internal lain dan juga strategi yang dianggap sesuai dengan situasi tutur untuk menjaga kesantunan bertindak tutur dengan mempertimbangkan petutur, tingkat solidaritas, dan tingkat tekanan. Sementara itu, keterbatasan kosakata memungkinkan mereka mengetahui hanya sedikit peranti pemerlunak, termasuk peranti pagar. Berdasar hasil wawancara, menjelang akhir perkulflahan sebenarnya mereka mengenal sebagian kata atau frasa yang sebenarnya bisa menjadi pagar dalam bertindak tutur memohon seperti mung.kin, barangkali, menurut saya, dan saya pikir. Mereka menyangka bahwa kata atau frasa tersebut hanya bisa digunakan untuk mengungkapkan tindak tutur representatif.

\section{b) Penggunaan Modifikasi Eksternal}

Berkaitan dengan penggunaan modifikasi eksternal, mahasiswa Jepang hanya menggunakan satu modifikasi eksternal, yaitu alasan pendukung, misalnya ketika mereka meminta dosen memperbesar tulisannya, penutur memberikan alasan bahwa dia tidak bisa membacanya. Peranti modifikasi eksternal lain tidak dipakai sama sekali seperti penyiap (preparators) yang terdiri atas mempersiapkan isi, mempersiapkan 
tindak tutur, mengecek ketersediaan, dan mencari prakomitmen; pemerdaya, pemanis, peminimalisasian biaya, dan berjanji memberi ganjaran juga tidak tampak dalam ujaran mereka.

Sehubungan dengan penggunaan, alasan pendukung sebagai peranti modifikasi eksternal utama, dapat dijelaskan berdasar temuan penelitian sebelumnya. Alasan pendukung (grounders), secara konsisten digunakan lintas bahasa sebagai peranti modifikasi eksternal jenis utama, baik oleh pemelajar maupun oleh penutur jati. Hal itu memberi alasan untuk menguatkan pandangan bahwa peranti yang paling masuk akal secara psikologis untuk mendukung tindak tutur memohon adalah alasan pendukung. Alasan pendukung merupakan peranti modifikasi eksternal lintas bahasa. Mahasiswa mengetahui bahwa tindak tutur memohonnya akan menjadi efektif jika didukung dengan modifikasi eksternal berupa alasan, baik berdasar pengetahuan dalam bahasa pertama maupun sebagai bagian dari dasar pengetahuan pragmatik umum. Semua penutur dalam berbagai bahasa juga menggunakan peranti itu.

Mahasiswa Program BIPA pun sudah menggunakan modifikasi eksternal berupa alasan pendukung ketika melakukan tindak tutur memohon meskipun penguasaan pragmalinguistik mereka masih minim. Hal itu dapat dijelaskan dari segi keeksplisitan makna proposisional. Alasan pendukung sebagai bagian dari modifikasi eksternal menyampaikan makna proposisional tuturan secara ekspl'isit dan mahasiswa secara sadar menggunakannya. Ada sejumlah alasan mangapa mahasiswa secara sadar menggunakan allasan pendukung dalam tindak tutur memohon mereka. Mahasiswa sangat ingin menggunakan alasan pendukung dalam tindak tutur memohon. Hal ini sebagai wujud kurang percaya diri dalam kemampuan membuat maksud tindak tutur memohonnya terpahami oleh petutur. Mungkin juga karena mereka kurang percaya diri dalam kemampuannya untuk menjadikan tuturannya menjadi santun.

Seharusnya untuk penggunaan modifikasi eksternal ini, mahasiswa Jepang tidak mengalami kesulitan karena penutur jati bahasa Jepang ketika melakukan tindak tutur memohon harus mengungkapkan penyesalannya. Ada beberapa ungkapan penyesalan karena mengganggu orang lain, yaitu summimasen-ga (Saya minta maaf, tetapi... oisogashii tokoro-o (ketika Anda sibuk), gomeewaku-towa omoimasu-ga (Saya tahu ini menyusahkan Anda, tetapi...). Hal itu dapat ditafsirkan dalam kesantunan bahasa 
Jepang, penutur jati bahasa Jepang bisa menggunakan modifikasi eksternal untuk memperlunak tindak tutur

\section{Simpulan}

Mahasiswa BIPA dari Jepang ketika melakukan tindak tutur memohon kepada dosen menggunakan strategi yang jauh lebih variatif dibanding ketika berinteraksi dengan sesama mahasiswa. Ada lima strategi vang digunakan, yaitu strategi imperatif (permohonan langsung), strategi performatif (permohonan langsung), strategi menanyakan kemampuan/kemauan dan menanyakan keterbolehan (keduanya masuk kategori tindak tutur tidak langsung secara konvensional yang berorientasi petutur), dan strategi isyarat (permohonan paling tidak langsung). Hal yang mengejutkan adalah penggunaan strategi imperatif dan performatif, yang keduanya adalah permohonan langsung. Strategi itu bagi penutur jati bahasa Indonesia dianggap tidak santun.

Perbedaan mencolok berkaitan dengan penggunaan strategi pada kedua kelompok petutur, yakni sesama mahasiswa dan dosen, yaitu tidak digunakannya strategi isyarat kepada petutur sesama mahasiswa. Meskipun persentasenya sangat kecil, mahasiswa mencoba menggunakan strategi isyarat ketika berinteraksi dengan dosen sebagai petutur. Hal itu dapat diinterpretasikan bahwa adanya kesadaran pembedaan strategi yang dipilih mahasiswa berkaitan dengan kekuasaan petutur.

Penggunaan strategi oleh mahasiswa Jepang, baik kepada sesama mahasiswa maupun dosen, terdistribusi secara merata pada hampir sernua kategori strategi, yaitu strategi imperatif (kategori permohonan langsung), strategi menanyakan kemampuan/kemauan/ keterbolehan (kategori tindak tutur tidak langsung secara konvensional berorientasi petutur), dan strategi isyarat (kategori permohonan paiing tidak Iangsung). Strategi yang tidak digunakan, baik kepada sesama mahasiswa maupun dosen, ialah tindak tutur tidak langsung secara konvensional yang berorientasi penutur. Namun, ada perbedaan persentase penggunaan strategi ketika berinteraksi dengan sesama mahasiswa dan dosen. Ketika berinteraksi dengan sesama mahasiswa, dominan menggunakan permohonan langsung, yakni strategi imperatif. Sementara itu, strategi yang digunakan ketika berinteraksi dengan dosen ialah tindak tutur tidak langsung secara konvensional yang berorientasi petutur, yakni strategi menanyakan kemampuan/kema uan/keterbolehan. Meskipun begitu, strategi imperatif, yang 
merupakan strategi perrpohonan paling langsung, tetap digunakan kepada dosen meskipun persentasenya mulai mengecil dibanding mahasiswa BIPA.

Berkaitan dengan penggunaan modifikasi internal, ada dua peranti sintaktik yang digunakan mahasiswa B1PA untuk memperlunak tindak tutur mernohonnya kepada petutur, yaitu menggunakan pertanyaan dan penyisipan. Mahasiswa juga menggunakan pernarkah kesantunan sebagai bagian dari phrasaI/lexical downgraders. Sementara itu, data penclitian tidak menunjukkan adanya penggunaan modifikasi eksternal oleh mahasiswa BIPA. Mahasiswa BIPA menggunakan peranti modifikasi internal berupa syntactic down-graders dan phrasa/lexical down-graders. Peranti syntactic downgraders yang digunakan ialah klausa kondisional dan pertanyaan, sedangkan peranti phrasal/lexical down-graders yang digunakan ialah penggunaan kata tolong, permisi, maaf, dan coba untuk mengawali tuturan.

Modifikasi eksternal yang digunakan mahasiswa BIPA ialah penggunaan alasan pendukung, yang ditempatkan pada bagian awal dan akhir tuturan. Mahasiswa BIPA menggunakan peranti modifikasi internal berupa syntactic down-graders dan phrasa/lexical down-graders. Peranti syntactic down-graders yang digunakan ialah pertanyaan dan klausa kondisional, sedangkan peranti phrasal/lexical down-graders yang digunakan ialah pemarkah kesantunan dan penanda antarpribadi. Data penelitian tidak menunjukkan adanya penggunaan modifikasi eksternal oleh mahasiswa BIPA.

\section{Daftar Pustaka}

Hildana, R Zulfira. 2014. "Tindak Tutur Ilokusi Representatif Dalam Komik Seratoes Ploes Aspirasi Karya Haryadhi: Sebuah Kajian Pragmatik" dalam Skriptorium Vol. 2 No. 2014-2.

Nasution, Khairina. 2007. "Tindak Tutur dan Perangkat Tindak Tutur dalam Bahasa Mandailing” dalam Historisme, Edisi No. 23/Tahun XI/Januari 2007.

Rahardi, Kunjana. 2005. Pragmatik: Kesantunan Imperatif Bahasa Imperatif Bahasa Indonesia. Jakarta: Erlangga.

Rusminto, N.E. 2010. Memahami Bahasa Anak-Anak. Bandar Lampung: Universitas Lampung. 
Journal Indonesian Language Education and Literature Vol. 2, No. 2, 2017

http://www.syekhnurjati.ac.id/jurnal/index.php/jeill/

Wawan, Danasasmita. 2007. "Efektivitas Model Directed Reading Actvity (DRA) dalam

Pengajaran Membaca Bahasa Indonesia Sebagai Bahasa Asing” dalam Educationist Vol. I No. 2/Juli 2007. 